\title{
Institutional role in coping livestock diseases on farm level in rural areas of Punjab, Pakistan
}

\author{
Hafiz Amjad Ali Rana ${ }^{1, *}$, Muhammad Iftikhar ${ }^{1}$, Muhammad Arif Watto ${ }^{2}$ and Muhammad Qamar Bilal ${ }^{3}$ \\ ${ }^{1}$ Institute of Agricultural Extension, Education and Rural Development, University of Agriculture, Faisalabad, Pakistan; \\ ${ }^{2}$ Institute of Agricultural Extension, Education and Rural Development, University of Agriculture, Faisalabad Sub-Campus \\ Depalpur Okara; ${ }^{3}$ Institute of Animal and Dairy Sciences, University of Agriculture, Faisalabad, Pakistan \\ *Corresponding author's e-mail: acyber310@gmail.com
}

\begin{abstract}
Livestock sector seeks a multifold increase in production to sustain its role in achieving food sufficiency in the world. However, anxiety is observed in terms of its falling production particularly in developing countries like Pakistan. The livestock sector is vulnerable to numerous diseases followed by poorly adopted coping strategies. This study was conducted in the Punjab Pakistan, a prominent province in terms of livestock production. A list of 3808 livestock farmers was developed through a benchmark survey conducted in two purposively selected (Raheem-Yar-Khan and Muzaffargarh) districts. A sample of 400 livestock farmers was determined from the 40 selected villages through a multistage sampling technique. Collected data were analyzed through SPSS and tables were drawn to interpret the results. Results indicate that awareness of farmers about different diseases was considerably good but the extent of damage theses disease gives to the livestock business was not understood by the farmers. Apart from foot-and-mouth disease and hemorrhagic septicemia farmers rated either low threatening or very low threatening. Farmers had poor knowledge about internal and external parasites and their damage was also not recognized by them. Only tick was reported as a farm damaging parasite. Though farmers were adopting coping strategies at the farms, but clean cattle shelter, vaccination and disease prevention were the leading practices. While against the services provided by the Punjab livestock department, only vaccination against the different disease was prominent. The education and experience of the farmers had a significant association with most of the coping strategies.
\end{abstract}

Keywords: Livestock disease, awareness, adoption, coping, association.

\section{INTRODUCTION}

The contribution of livestock in agriculture is $60.56 \%$ and nearly $11.69 \%$ in the total gross domestic product of Pakistan (GOP, 2020). Pakistan occupies the second position in possessing the number of buffaloes (Hegde, 2019), the eighth position in the number of cattle (FAO, 2021), and the third position in the number of goats (Miller and Lu, 2019). Pakistan is the $4^{\text {th }}$ largest milk-producing country in the world (FAO 2020). Punjab which is the $2^{\text {nd }}$ largest province of Pakistan by area (GOP, 2016) contains more than 84 million animals (GOP, 2018).

Livestock has the potential in alleviating poverty (Khan et al., 2015), achieving food security (Devendra, 2005), allowing employment (Sidhu and Bhullar, 2004), managing sustainable livelihoods and improving the economy (Martin et al., 2020). In a country such as Pakistan where a huge number of farmers have a small piece of land (Raza et al., 2020) highly dependent on livestock as it is the central breadwinning force besides growing crops (Rehman et al., 2017)

Pakistan is the fourth largest country in the world regarding the livestock population (Randhawa et al., 2018). The escalating number of livestock with low production can also be a serious threat to the shrinking resources i.e., water, fodder, pastures and space, etc. (Shahid et al., 2012; Davidson et al., 2000; Thornton, 2010). Old fashioned style of management costing a lot. In the developed countries (i.e., USA, UK, New Zeeland, etc.) the number of livestock farmers had decreased but the overall production has gone up (MacDonald et al., 2006; Abdullah, 2009). A comparison of average milk production between different countries shows that one New Zealand cow produces three times more than that of Pakistani cows while on the other hand, one American cow manages to produce round about seven Pakistani cows (Abdullah, 2009). This dramatic difference in productivity is due to several factors, including genetic and management

Rana, H.A.A., M. Iftikhar, M.A. Watto and M.Q. Bilal. 2021. Institutional role in coping livestock diseases on farm level in rural areas of Punjab, Pakistan. Pak. J. Agri. Sci.58:1411-1421.

[Received 18 Nov 2020; Accepted 28 Jun 2021; Published (online) 21 Sep 2021] 
technologies (Derner et al., 2017). Fortunately, many of these factors are known, suggesting great potential for the development of the local dairy sector (FAO, 2019).

Farmers are exposed to a number of problems such as the onset of infectious disease, duration of illness of animals, nutrition costs, vaccination costs and poor management (Benkirane and Alwis, 2002). Diseases have a bad impact on livestock production in the form of treatment costs, prevention, technical assistance, lowered performance and/or quality of feedstock (Lopes et al., 2015).

Poor extension services and unwise use of resources to combat animal diseases are significant (Faraz et al., 2018). Many of the lethal diseases had been reported to cost a farmer a huge loss in the form of a reduction in milk/meat production and expiry of animals (Ashfaq et al., 2015). Farmers were unable to identify the diseases due to a lack of awareness which results in poor attention and management of these diseases. Often the farmers ignore the timely vaccination of their animals which could have kept their animals healthy (Sarke et al., 2020). They do what makes sense to them in a particular situation (Jamal et al., 2010).

One out of four buffalo or cows were found suffering from misstates (Ferrari et al., 2014). Moustafa et al. (2017) reported $58.7 \%$ of the animals' deaths due to five endemic diseases like HS, FMD, rinderpest, anthrax and blackleg. Previously due to five economical endemic diseases, $58.7 \%$ of deaths were reported. Ticks and tick-borne diseases are responsible for the massive loss of productivity and income. Ticks can cause anemia, loss of body weight, reduced milk production, loss of body weight, udder damage (Biegelmeyer et al., 2015).

Both, buffalo and cow are susceptible to tick-borne disease but cow is more vulnerable as compared to water buffalo and in cows' exotic animals are on the red line (Jabbar et al., 2015; Ahmad et al., 2019). Severe parasites cause gastroenteritis and blood protozoa (Rashid et al., 2019). Farmers' ignorance of general surveillance measures makes it more difficult to control parasites, such as pest control and vector-related diseases (Sarwar et al. 2002).

Animal health is essential to prevent delays in the production of animals. There are many veterinary hospitals and pharmacies, but the benefits are not being given to farmers. Vaccination programs against diseases (FMD) are not being frequently used (Sarwar et al., 2002). The subsistence nature of Pakistani livestock farmers and the high prices of dairy animals, farmers cannot afford to lose their animals due to rampant diseases. Mortality and low productivity caused livestock disease which posed a great threat to the overall well-being of poor farmers (Husnain and Usmani, 2006).

The role of institutions and advisory services is augmented key in order to sustain the livestock sector. The advisory service providers are meant to serve farmers, educate them about the management of animals, persuade them to adopt relevant techniques and enrich the farmers with proper supply of medicine (Shahbaz and Ata, 2014; Faraz et al., 2019; GOP 2016). Ashraf et al. (2019) argued that the public sector enjoys the different types of allowances to educate the farmers. Public sector intended to provide on-farm advocacy, arranging training/workshops and arranging agricultural fares for farmers (Farooq et al., 2020).

There is a huge gap between the average milk production per animal and the maximum milk produced by the animal. The average milk production in the country is as same as it was in the past. The growth rate in milk production is due to the increasing number of animals. It is imperative to break through this 6, 7 litter average per animal in the country. Identifying the role of advisory service providers is poorly discussed in the literature with special reference to Pakistan. Therefore, exploring the role of advisory service providers could help policy practitioners to amend the role in the well need of the farmers to boost the livestock sector. The public sector (Punjab livestock \& dairy development board) is meant to provide livestock farmers in production, processing and marketing with modern farming technologies to improve their animals' genetics and milk/ meat production ratio. There might be some flaws and loopholes which need to be considered in the future. There are very fewer studies that address institutional role in coping with livestock diseases on the farm level and equip decision-maker at the provincial and then national level with baseline information and strategic assessment on the livestock sector. This study was deadly needed in where the literature on the institutional role with livestock was very much scanty, scattered, or silent. Therefore, the current study was planned to make a scientific effort to probe out the institutional role in coping with livestock diseases on the farm level in Punjab Pakistan and their management with greater efficiency. On a bigger spectrum, this study could unveil the special implications to address the need of developing countries.

\section{Objectives of the study}

1. Exploring the demographic profile of respondents

2. Identifying the different diseases as witnessed by the farmers faced by their animals

3. Institutional role in helping farmers to cope with the diseases to make their animal productive

4. Exploring the determinants of adoption of coping strategies among livestock farmers and implications for the advisory service providers

\section{MATERIALS AND METHODS}

Selection of study area: Punjab is a key province of Pakistan in terms of agricultural potential. It has 4.20 million hectares of cultivated areas. Livestock is a subsector of agriculture and Punjab is the leading province in livestock having a population of 73,677,851 individuals (GOP, 2018). Buffalo is a major dairy animal in Pakistan. There are five well-known breeds of buffalo in the country: Nili, Ravi, Nili-Ravi, Azi 
Kheli (or azakhale) and Kundhi. (Deb et al., 2016). There are a large number of cattle breeds including exotic breeds. Well know breeds are Sahiwal, Red Sindhi, Cholistani, Achai, Tharpaker, crossbred animals and exotic breeds. However, the majority of cattle (i.e., 60- 70\%) in Pakistan are nondescript animals without well-defined type and production characteristics (Ishaq et al., 2016).

There are total 36 districts in Punjab and almost all are directly or indirectly associated with livestock populations. Of the total 36 districts, 02 districts such as Rahim Yar Khan and Muzaffargarh were selected purposively as the study area. Both districts had the maximum number of cattle ad buffalo in Punjab (GOP, 2018). Thus, it became easy to select these two districts.

Selection of sample: A multi-stage sampling technique was adopted to select the sample. At the first stage, two districts Muzaffargarh and Rahim Yar Khan were selected from the Punjab province. Both districts, Muzaffargarh and Rahim Yar Khan had four tehsils (sub-districts) each. At the second stage, from each selected district two tehsils were randomly selected.

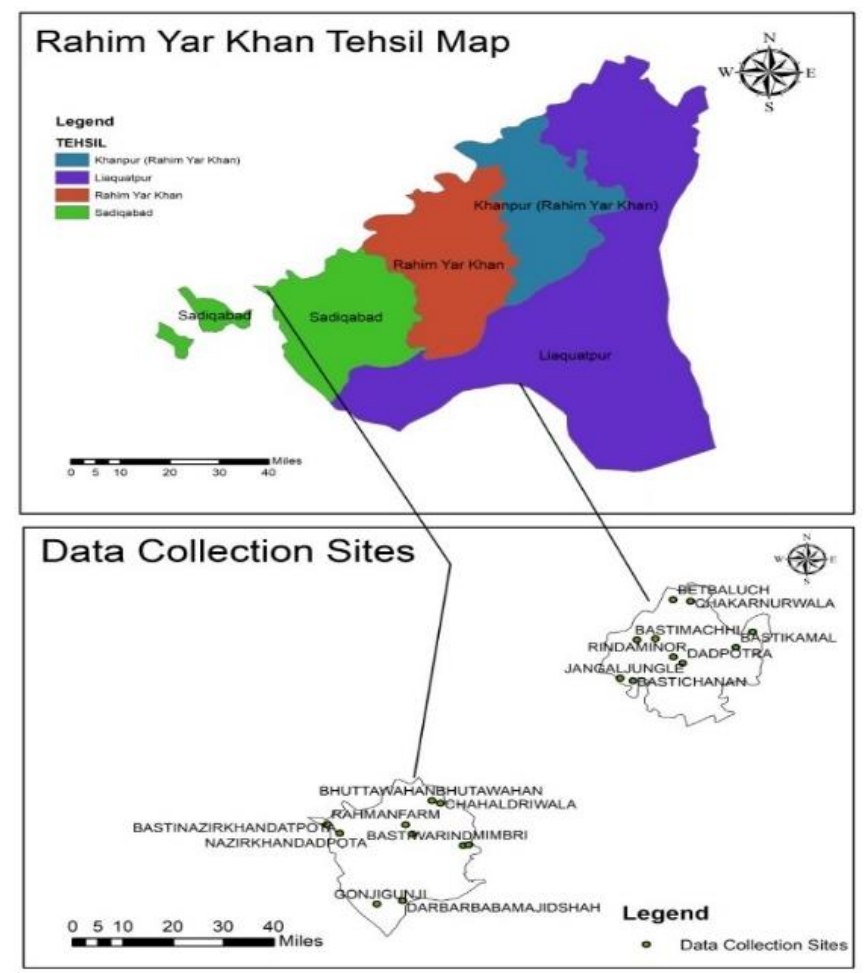

Figure 1. Rahim Yar Khan selected tehsils and different villages sites

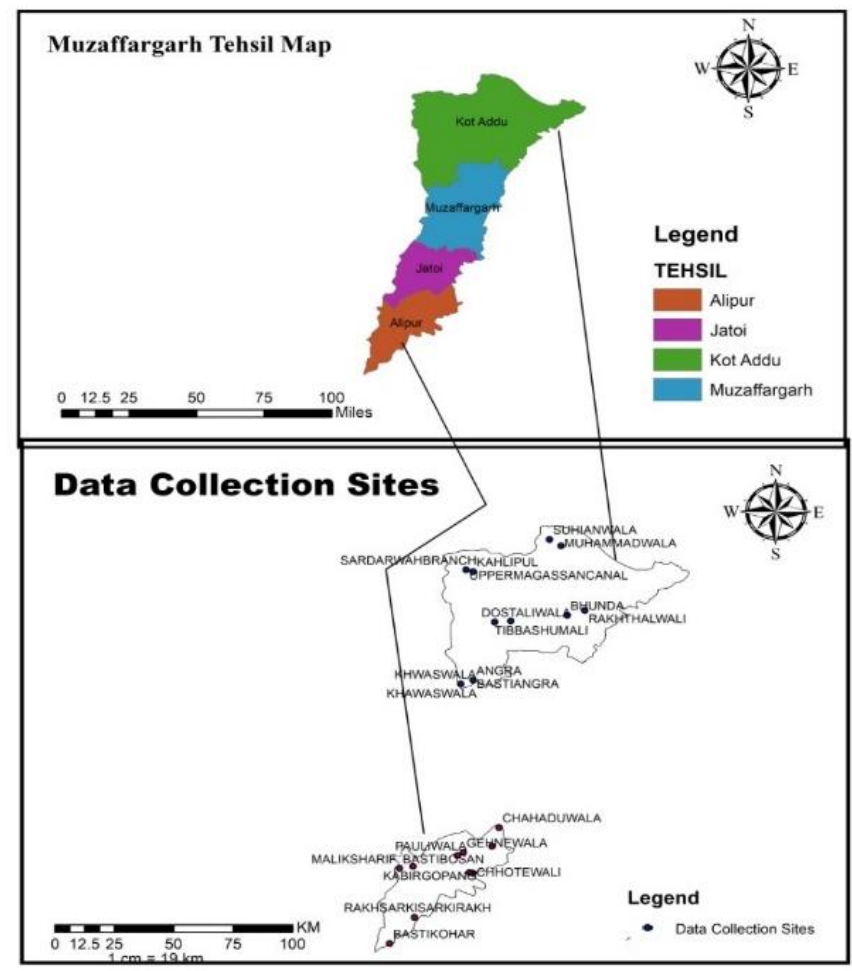

Figure 2. Muzaffargarh selected tehsils and different villages sites

From Rahim Yar Khan, Liaquatpur (comprising of total 25 Union Councils) and Sadiq Abad (29 Union Councils) tehsils and from Muzaffargarh, Alipur (20 Union Councils) and Kot Addu (28 Union Councils) tehsils were selected at random.

At the third stage of sampling, five rural union councils from each selected tehsil were selected randomly, thereby making a pool of 20 UCs. At the fourth stage, two villages from each selected union council were selected resulting in total 40 villages (see figure 1 and figure 2). Different villages selected from the four selected tehsils are illustrated on the map developed with the help of Arc Gis 10.3.1 software. For the selection of the final sample, a benchmark survey of 40 selected villages was conducted with the help of local leaders and progressive farmers. A list of 3808 livestock farmers was developed with this benchmark survey. From the 3808 farmers of 40 selected villages (10 from each selected village), 400 farmers were selected randomly.

Validity and reliability of the research instrument: A research instrument is said to be valid if it measures what it intends to measure. For technical validity appointment was taken from a Professor of the Faculty of Animal Husbandry and a veterinary doctor. He checked the manuscript and suggestions made by him have been incorporated accordingly. For reliability test/retest method and Cronbach's Alpha were used. Twenty farmers interviewed during the pretest of the interview schedule were re-interviewed using 
the same instrument a few days later. Responses from both rounds were compared and found to be generally consistent in most cases. Some minor inconsistencies were noted, particularly in questions where scales were used to measure the extent of something. Cronbach's Alpha was measured through the Statistical Package for Social Sciences (SPSS). The average value of internal consistency emerged was 0.751 . Data collection and analysis: In the current study, the survey research design was used. Furthermore, the study was descriptive, and a cross-sectional design was adopted. Initially, the collected data were put in the Excel sheet instead of SPSS as it is more secure and reliable for a long time. Both descriptive and inferential statistics were used to determine the association between the demographic profile of respondents and the adoption of different coping strategies

\section{RESULTS}

Demographic profile of the respondents: Farmers falling in the age bracket of more than 50 years were prominent $(43.3 \%)$. Of the total farmers, $39.8 \%$ were aged between 31 and 50 years. Significantly less than one fifth $(17 \%)$ were considerably young. The mean age value of the respondents was 44.1 years. The findings indicate more interest of old age farmers in livestock keeping as compared to young. This age difference could set a significant influence over the adoption of site-specific technologies.

Regarding education, $21 \%$ of farmers were illiterate and $4.5 \%$ of farmers had the ability just to read or write. Almost one third of respondents $(34.8 \%)$ had a primary level of education. Out of total farmers, $11.8,5$ and $1 \%$ had an educational level of higher, graduation and post-graduation, respectively. The mean education of the respondents was 7.4 years. Results were somewhat in line with that of Mangan and Ruthbah (2018) who reported in policy and institutional reforms to improve horticultural markets in Pakistan that near about three fourth $(72.66 \%)$ of the respondents were able to read or write. The overall educational level in the region was ordinary and this could be the reason behind the poor productivity of the livestock in the study areas.

More than half $(53.8 \%)$ of respondents had family members between 5 to 10 . More than one fourth $(28.5 \%)$ had less than

Table 1. Demographic profile of respondents.

\begin{tabular}{|c|c|c|c|c|c|c|}
\hline \multicolumn{2}{|c|}{ Demographic profile of respondents } & $f$ & $\%$ & Min. & Max. & $\overline{\mathbf{x}}$ \\
\hline \multirow[t]{3}{*}{ Age } & Young $(>18$ to $<30$ years) & 68 & 17.0 & & & \\
\hline & Middle ( $>31$ to $\leq 50$ years) & 159 & 39.8 & 22 & 64 & 44.1 \\
\hline & Old (> 50 years) & 173 & 43.3 & & & \\
\hline \multirow[t]{8}{*}{ Education } & Absolute illiterate & 83 & 21.0 & & & \\
\hline & Can read or write (but no proper schooling) & 18 & 4.5 & & & \\
\hline & Primary & 139 & 34.8 & & & \\
\hline & Middle & 49 & 12.2 & & & \\
\hline & Secondary & 39 & 9.8 & 0 & 18 & 7.4 \\
\hline & Higher secondary & 47 & 11.8 & & & \\
\hline & Graduation & 20 & 5.0 & & & \\
\hline & Above graduation & 4 & 1.0 & & & \\
\hline \multirow[t]{3}{*}{ Family size } & Less than 5 members & 114 & 28.5 & & & \\
\hline & 5 to 10 members & 215 & 53.8 & 0 & 13 & 8.3 \\
\hline & Above 10 members & 71 & 17.7 & & & \\
\hline \multirow[t]{4}{*}{ Land size } & Land less farmers & 52 & 13.0 & & & \\
\hline & Small farmers (less than 12.5 acres) & 260 & 65.0 & & & \\
\hline & Medium farmers ( 12.5 to 25 acres) & 71 & 17.8 & & & \\
\hline & Large farmers (above 25 acres) & 17 & 4.3 & 0 & 210 & 4.9 \\
\hline \multirow{4}{*}{$\begin{array}{l}\text { Livestock rearing } \\
\text { experience }\end{array}$} & Less than 5 years & 18 & 4.5 & & & \\
\hline & 5 to 10 years & 154 & 38.5 & & & \\
\hline & 11 to 15 years & 110 & 27.5 & 2 & 30 & 12.7 \\
\hline & Above 15 years & 118 & 29.5 & & & \\
\hline \multirow[t]{4}{*}{ Income source } & Only livestock & 78 & 19.5 & & & \\
\hline & Livestock + Crop farming & 173 & 43.3 & - & - & - \\
\hline & Livestock + Other Farming & 38 & 9.3 & & & \\
\hline & Livestock + Other & 111 & 27.7 & & & \\
\hline Purpose of & Fattening for meat purpose & 6 & 1.5 & & & \\
\hline \multirow{3}{*}{ livestock keeping } & Breading & 57 & 14.2 & - & - & - \\
\hline & Dairy & 178 & 44.5 & & & \\
\hline & Mix & 159 & 39.8 & & & \\
\hline
\end{tabular}


5 and $17.7 \%$ of farmers had considerably large families. On average respondents had 8.3 members in the family, possibly large families can contribute with the households' head while managing the livestock.

In terms of land size, $13 \%$ of farmers were landless and a major chunk of farmers $(65 \%)$ was small landholders. The average land size was 4.9 acres in the study area. Managing livestock with no land or small landholdings might affect production. Sometimes, the cost of production may increase, when having no land, means farmers buy all the required feed from the local market.

Farmers had a different genre of experience. About $30 \%$ of respondents had an experience of over 15 years, Perhaps, these were the most experienced farmers in terms of keeping animals. Only $4.5 \%$ of farmers had less than 5 years of experience. On average farmers had 12.7 years of experience in the study area. They could be the young farmers involved in livestock in recent years. This is in consents with the age of farmers as young age respondents were few who have adopted the livestock keeping.

One fifth of respondents (19.5\%) arbitrated livestock as their sole income source whereas, for the rest of the farmers, livestock was a secondary income source along with other sources like crop farming (43.3\%), other farming $(9.3 \%)$ and other sources $(27.7 \%)$. In order to generate income, $44.5 \%$ of respondents were keeping livestock for dairy purposes. About $40 \%$ of respondents' purpose of livestock keeping was mixed, including breading and dairy purpose. A negligible number of respondents had livestock for meat purposes. This indicates that livestock keeping among farmers was domestic rather than commercialized in nature.

Livestock diseases perceived by farmers: Farmers were asked to explore the perceptions regarding different diseases of animals such as Foot and mouth disease, Hemorrhagic Septicemia, Milk fever, Mastitis, Impaction, Retain placenta, Diarrhea, Black quarter, Ketosis, Anthrax, Tuberculosis, Tympany, Pneumonia, Vaginal prolapse and Metritis.

Table 2 shows that majority of the respondents had awareness about foot and mouth disease $(89.7 \%)$, hemorrhagic septicemia $(93.7 \%)$, tympany $(95.0 \%)$, mastitis $(86.2 \%)$, impaction $(88.7 \%)$ and diarrhea $(81.2 \%)$. Conversely, the farmers had poor awareness about milk fever (37.0\%), black quarter $(36.0 \%)$, tuberculosis $(21.0 \%)$ and metritis $(29.2 \%)$. Paralyze, vomiting, cough, stress, etc. were recognized by nearly $60 \%$ of the respondents. There were some healthrelated problems of buffalo and cow which were beyond the knowledge level of farmers.

In the context of the damage, foot and mouth disease $(\bar{x}=3.30)$ and hemorrhagic septicemia $(\bar{x}=3.22)$ were the leading common diseases with a high level of damage to the animals. The extent of damage was of more than medium level as perceived by the farmers but of good strength in order to damage the animals severely. Milk fever was ranked in terms of its damage to the animals $(\bar{x}=2.56)$. Mastitis was the $4^{\text {th }}$ $(\bar{x}=2.50)$ and impaction $(\bar{x}=2.45)$ was ranked $5^{\text {th }}$ for the damage caused to animals as perceived by the farmers. During an informal conversation with respondents, it was observed that farmers consider their animals sick only when they stop eating fodder or drinking water. Only extreme conditions were considered at the farm. Respondents ranked economic loss between medium to moderate, but FAO (2014) summarized that just because of this disease animal loss can go up to $33 \%$ of the total produce.

Internal and external parasitic: In this study, internal and external parasites were categorized into different types i.e.

Table 2. Types of diseases for the livestock as witnessed by the farmers

\begin{tabular}{|c|c|c|c|c|c|}
\hline \multirow[t]{2}{*}{ Disease types } & \multicolumn{2}{|c|}{ Awareness } & \multirow{2}{*}{$\begin{array}{c}\text { Perceived extent of damage } \\
\overline{\mathbf{x}} \pm \text { S.D }\end{array}$} & \multirow[t]{2}{*}{ W.S. } & \multirow{2}{*}{$\begin{array}{l}\text { R.O. based } \\
\text { on } \bar{x}\end{array}$} \\
\hline & Frequency & Percentage & & & \\
\hline FMD & 359 & 89.7 & $3.30 \pm 1.48$ & 1183 & 1 \\
\hline Hemorrhagic septicemia & 375 & 93.7 & $3.22 \pm 1.12$ & 1206 & 2 \\
\hline Milk fever & 148 & 37.0 & $2.56 \pm 1.33$ & 379 & 3 \\
\hline Mastitis & 345 & 86.2 & $2.50 \pm 1.34$ & 862 & 4 \\
\hline Impaction & 355 & 88.7 & $2.45 \pm 1.262$ & 868 & 5 \\
\hline Retain placenta & 370 & 92.5 & $2.44 \pm 1.011$ & 904 & 6 \\
\hline Diarrhea & 325 & 81.2 & $2.28 \pm 1.090$ & 740 & 7 \\
\hline Black quarter & 144 & 36.0 & $2.20 \pm 1.001$ & 317 & 8 \\
\hline Ketosis & 271 & 69.2 & $2.17 \pm 1.191$ & 589 & 9 \\
\hline Anthrax & 297 & 74.2 & $2.09 \pm 1.111$ & 622 & 10 \\
\hline Tuberculosis & 84 & 21.0 & $1.95 \pm 0.863$ & 164 & 11 \\
\hline Tympany & 380 & 95.0 & $1.93 \pm 0.939$ & 732 & 12 \\
\hline Pneumonia & 305 & 76.5 & $1.92 \pm 0.946$ & 586 & 13 \\
\hline Paralyze, vomiting, cough, stress etc. & 234 & 58.5 & $1.82 \pm 0.953$ & 427 & 14 \\
\hline Vaginal prolapse & 278 & 69.5 & $1.63 \pm 0.865$ & 452 & 15 \\
\hline Metritis & 117 & 29.2 & $1.60 \pm 0.696$ & 187 & 16 \\
\hline
\end{tabular}

Scale 1= Very Low, 2= Low, 3= Moderate 4= High, 5= Very High 
Rana, Iftikhar, Watto \& Bilal

Table 3. Distribution of livestock farmers according to the internal and external parasite

\begin{tabular}{|c|c|c|c|c|c|}
\hline \multirow[t]{2}{*}{ Internal and external parasite } & \multicolumn{2}{|c|}{ Recognize } & \multirow{2}{*}{$\begin{array}{c}\text { Perceived extent of damage } \\
\overline{\mathbf{x}}+\mathrm{SD}\end{array}$} & \multirow[t]{2}{*}{ W.S. } & \multirow{2}{*}{$\begin{array}{l}\text { R.O. based } \\
\text { on } \bar{x}\end{array}$} \\
\hline & Frequency & Percentage & & & \\
\hline Ticks & 387 & 96.8 & $3.19+1.396$ & 1233 & 1 \\
\hline $\begin{array}{l}\text { Heartworms, hookworms, } \\
\text { hairworms, grubs, etc. }\end{array}$ & 11 & 97.3 & $2.09+0.831$ & 23 & 2 \\
\hline Lungworms & 222 & 55.5 & $1.90+0.932$ & 422 & 3 \\
\hline Tap worms & 113 & 28.2 & $1.86+0.822$ & 210 & 4 \\
\hline Roundworms & 200 & 50.0 & $1.85+0.981$ & 370 & 5 \\
\hline Lice & 163 & 40.8 & $1.68+0.709$ & 274 & 6 \\
\hline Mites & 286 & 71.5 & $1.65+0.853$ & 471 & 7 \\
\hline Liver flukes & 284 & 71.0 & $1.62+0.701$ & 459 & 8 \\
\hline Warble fly & 162 & 40.5 & $1.60+0.663$ & 260 & 9 \\
\hline
\end{tabular}

Scale $1=$ Very Low, $2=$ Low, $3=$ Moderate $4=$ High, $5=$ Very High

Table 4. Distribution of livestock farmers according to the management strategies against different livestock diseases.

\begin{tabular}{lccccc}
\hline Management strategies & \multicolumn{2}{c}{ Yes } & Perceived extent of management & W.S. & $\begin{array}{c}\text { R.O. based } \\
\text { on } \overline{\mathbf{x}}\end{array}$ \\
\cline { 2 - 5 } & Frequency & Percentage & $\overline{\mathbf{x}}+$ SD & 1539 & 1 \\
Clean cattle shelter & 400 & 100.0 & $3.85+1.24$ & 1476 & 2 \\
Vaccination & 400 & 100.0 & $3.21+1.22$ & 1410 & 3 \\
Disease prevention & 388 & 97.0 & $3.10+1.33$ & 1037 & 4 \\
Parasite control & 361 & 90.3 & $2.55+1.40$ & 780 & 5 \\
Separate cattle pen & 227 & 69.3 & $2.44+1.42$ & 570 & 6 \\
Adopting resistant breed & 244 & 61.0 & $2.10+1.35$ & 8 & 7 \\
Animal discard, stop visitors in & 8 & 2.0 & $1.0+0.00$ & & 8 \\
the farm, restricted graing, etc & & & &
\end{tabular}

the farm, restricted grazing, etc.

Scale $1=$ Very Low, $2=$ Low, $3=$ Moderate $4=$ High, $5=$ Very High

ticks, lungworms, tap worms, roundworms, lice, mites, liver flukes and warble fly.

Table 3 confides that internal and external parasite ticks (96.8\%) were the only one about which an overwhelming majority of the respondents knew apart from that farmers also observed different types (Heartworms, hookworms, hairworms, grubs, etc.) of the internal and external parasite $(97.3 \%)$ some of them also claimed that they don't know what types of these creatures were. About three fourth of the respondents were also aware of the mites and liver flukes. Half of the interviewed people had also knowledge about long and tap worms. Damage to the herd just because of tick $(\bar{x}=$ 3.19) was rated between moderate to a high level. Respondents further explored during the informal discussion that tick was a real threat to cross-bread or exotic animals. Indigenous breeds fight against it and hardly let it damage herd performance. Damage gave by Heartworms, hookworms, hairworms, grubs, etc. $(\bar{x}=2.09)$, lungworms $(\bar{x}=1.90)$, tap worms $(\bar{x}=1.86)$, roundworms $(\bar{x}=1.85)$, lice $(\bar{x}=1.68)$, mites $(\bar{x}=1.65)$, liver flukes $(\bar{x}=1.62)$ and warble fly $(\bar{x}=1.60)$ to the herd as perceived by the respondents was raked just very low to low. Internal parasites cause diarrhea, weakness, hair loss, lacrimal discharge, pendulous abdomen, loss of production and submandibular edema they further elaborated. About one-fourth (28.2\%) of respondents know tap worms and a little bit above half is known to lungs and roundworms.

Management strategies: Different coping strategies adopted by the farmers in the livestock business for disease prevention may include parasite control, clean cattle shelter, separate cattle pen, vaccination, adopting resistant breed and disease prevention.

An overview of Table 4 describes the different strategies adopted by the farmers to manage with different types of diseases at their farm and the level of adaptability. All the farmers clean their shelter $(\bar{x}=3.85)$ and vaccinate their animals $(\bar{x}=3.21)$ to avoid disease setting and their means were spotted between moderate to high. It is customary for a livestock keeper to clean their shed twice a day to look it better and germ-free. For vaccination, they heavily depend on the Government vaccination campaign, but it never covers all types of vaccination mandatory for the animal against different diseases and parasite attacks. But it was sure they visit the farm and vaccinate animals against some disease. Nearly all $(97.0 \%)$ take different preventive measures like proper nutrition, herd management, taking care of the extreme climatic condition, checking disease spread, and also care about the health of the handler. to tackle disease outbreak and to stop its spreading to the other animal. An overwhelming majority $(90.3 \%)$ try to control different parasites of the 
Table 5. Institutional role in the provision of services to adopt management strategies among farmers.

\begin{tabular}{lccc}
\hline Field services to the livestock farmers & Perceived extent of service & W.S. & R.O. based on $\overline{\mathbf{x}}$ \\
\cline { 2 - 2 } & $\overline{\mathbf{x}}+$ SD & & \\
\hline Vaccination of hemorrhagic septicemia & $3.64+1.369$ & 1457 & 1 \\
Vaccination of foot and mouth disease & $3.07+1.288$ & 1228 & 2 \\
Vaccination of black quarter & $3.02+1.627$ & 1206 & 3 \\
Treatment of sick animal & $1.80+1.027$ & 719 & 4 \\
Mobile vet services & $1.71+1.229$ & 683 & 5 \\
Deworming against endo-parasites and ecto-parasites & $1.60+1.088$ & 589 & 6 \\
Dehorning/ disbudding & $1.53+1.169$ & 575 & 7 \\
Artificial insemination & $1.50+0.986$ & 598 & 8 \\
Castration of male animal & $1.26+0.833$ & 504 & 9 \\
Registration of animals, registration of herd, animal & $1.23+0.793$ & 429 & 10 \\
competition, etc. & & & \\
\hline
\end{tabular}

Scale $1=$ Never, $2=$ Rarely, $3=$ Some Time, $4=$ Very Often, $5=$ Always

Table 6. Determinants of the adoption of coping strategies.

\begin{tabular}{lcccccc}
\hline Variables & $\begin{array}{c}\text { Clean cattle } \\
\text { shelter }\end{array}$ & Vaccination & $\begin{array}{c}\text { Disease } \\
\text { prevention }\end{array}$ & $\begin{array}{c}\text { Parasitic } \\
\text { control }\end{array}$ & $\begin{array}{c}\text { Separate } \\
\text { cattle pen }\end{array}$ & $\begin{array}{c}\text { Adopting } \\
\text { resistant breed }\end{array}$ \\
\hline Age & 0.020 & $-0.063^{*}$ & 0.054 & 0.050 & -0.130 & $0.078^{*}$ \\
Education & 0.058 & $0.014^{*}$ & $0.075^{*}$ & $0.036^{*}$ & $0.026^{*}$ & $-0.023^{*}$ \\
Family size & 0.083 & -0.011 & 0.012 & 0.073 & 0.038 & -0.011 \\
Land size & 0.048 & 0.020 & -0.072 & 0.081 & -0.033 & 0.031 \\
Tenancy & 0.014 & -0.029 & 0.012 & 0.024 & -0.054 & 0.029 \\
Livestock experience & -0.012 & -0.092 & $0.035^{*}$ & $0.029^{*}$ & 0.038 & $0.055^{*}$ \\
Income source & 0.021 & 0.063 & 0.082 & 0.077 & 0.116 & 0.041 \\
Livestock nature & -0.036 & $0.056^{*}$ & 0.061 & 0.005 & 0.008 & $-0.019^{*}$ \\
\hline
\end{tabular}

*Indicates significant at $95 \%$ confidence interval

animal. Above one third (69.3\%) of the farmers try to identify the sick animal and remove from the herd to stop its spreading to the whole farm. Respondents further particularized that they keep sick animal isolated to feel it relax and treat it properly until it recovers and start to perform.

Field services to the livestock farmers provided by the public sector:

Punjab livestock department is providing field services to the livestock farmers. These services may include vaccination of different diseases, treatment of a sick animal, mobile vet services, deworming against endo-parasites and ectoparasites, dehorning/ disbudding, artificial insemination and castration of male animal.

The reflection of Table 5 discloses the level of different field services provided by the Punjab livestock \& dairy development board in the study area. Vaccination of hemorrhagic septicemia was the leading service provided by the Punjab livestock department with a mean value of 3.64 having a standard deviation of 1.369 and its weighted score was 1457 . Vaccination of foot and mouth was ranked $2^{\text {nd }}$ by the farmers with a mean value of 3.07 having a standard deviation of 1.288 and its weighted score was 1228 . Vaccination of the black quarter was ranked $3^{\text {rd }}$ in the list. Treatment of sick animals at farm level $(\overline{\mathrm{x}}=1.80)$ and mobile veterinary services $(\overline{\mathrm{x}}=1.71)$ were also rare. Informally they explored these services are useless for the farmers in an emergency situation. The overall scenario of the Table confides poor health services in the study area. Except for vaccination, other services were diminishing on the farm.

Farmer's demographic profile had an association with different coping strategies implemented by the farmers at the farm. Age of the farmer had a significant association (-0.063) with animal vaccination but it was negatively associated while resistant breed was positively associated (0.078) with farmer age. This negative association is may be due to the diverse age of the respondents. The higher the age goes of the herder lesser the animal gets vaccinated at the farm while on the other hand, aged people like to have an indigenous breed that is more resistant to unusual circumstances. Education was statistically significant $(\mathrm{P}<0.05)$ and positively associated with vaccination $(0.014)$, disease prevention $(0.075)$, parasite control (0.036), separate cattle pen (0.026).

Land size and tenancy had a non-significant association with strategies likely to be adopted by the farmers. Livestock experience had a significant positive association with parasite control (0.029), disease prevention (0.035) and adopting resistant breed (0.055). With the experience, farmers get more exposure to different situations and handle disease setting and parasite control. As the experience mounts up farmers get more knowledge about different breeds and this experience to 
enable them to go for the resistant breed for safe herding. The nature of livestock herding was positively associated with vaccination (0.056).

\section{DISCUSSION}

The present study for the first time investigates the knowledge level of farmers regarding different types of important diseases and parasites their coping strategies at the farm level along with the role played by the public sector to combat these misfortunes. The demographic profile of farmers and its association was identified. Famer had poor knowledge except for some recognized diseases. Foot and mouth disease, Hemorrhagic Septicemia, Mastitis and Milk were the most recognized diseases of animals as perceived by farmers (Idrees et al., 2007). Findings are different from those of Ashfaq et al. (2014) as they found mastitis as a widely known disease. The high level of awareness about most of the diseases among farmers may be attributed to the role of advisory services providers and other sources like electronic media, print media and modern gadgets of social media. Due to unawareness about the different diseases, farmers only count the damage of foot and mouth disease and hemorrhagic septicemia. While milk fever was identified as devastating for the animals by DeGaris and Lean (2008). They concluded that the prevalence of milk fever was $25 \%$ in the field. The prevalence surged to $80 \%$ in research trials as well. Though, farmers had poor awareness and identification of this disease due to its close resemblance with other disease symptoms (Thilsing-Hansen et al., 2003). Consequently, farmers' economic gains were declined due to milk fever (Fikadu et al., 2016). Likewise, vaginal prolapse is a life-threatening disease as discussed by Fareed et al. (2017). Their results indicate that out of a total of 46 reported cases 10 animal expired while on the other hand not a single animal pass away due to abortion (number of cases 380), repeat breeding (number of cases 296), dystocia (number of cases 130), vaginitis (number of cases 18) and mastitis (number of cases 102). Tuberculosis which can trigger huge economic loss since it can check national and internarial trade of animal and animal product (Dejene et al. 2016) but respondents awareness was very poor only one fifth $(21.0 \%)$ of the total respondents recognized it. Ullah et al. (2019) also confide that handler or the owner of the herd failed to identify the symptoms, signs and nature of the infection.

Tick was the only parasite in external and external which was a nightmare for most of the farmers. Rehman et al. (2017) and Rashid et al. (2018) discussed the restlessness of investors on exotic breed just because of ticks found in the region. Tick infestation diminishes the quality of skin/hide up to $20-30 \%$ (Gharbi et al., 2006) and causes severe loss of production, weakens the immune system which invites other diseases (Gwakisa et al., 2001). The knowledge level of the farming community in the study area regarding the rest of the parasite had been a kind of concern. Haleem et al. (2018) endorsed the finding as he motioned in their study that $97.9 \%$ of the farmers have no know-how about the presentation and transmission of these worms from one to another. Tap worms and lungs and roundworms which alone cost Rs. 11.47 billion in India annually (Singh et al., 2015) were not identified by the majority of the farmer.

To combat disease outbreaks at the farmers adopt the strategy of cleaning the shed and vaccinating animals before its set. Klein et al. (2008) also endorsed these results as they claimed $88 \%$ of the animal at Landhi Dairy Colony get vaccination but on the other hand. In fact, animals are vaccinated annually, but it cannot be more than $10 \%$ of the population. Vaccination programs against diseases (for example, foot-and-mouth disease) are not being frequently used (Sarwar et al., 2002). Self-isolation may or may not be observed but the handler has to identify these animals and isolate them from the herd (Proudfoot et al., 2014) adaptability of resistant verity was a practice for less than one-third $(61.0 \%)$ of the total. In informal conversation, it was observed that they like to keep indigenous breeds like Sahiwal resistant to tick (Faraz, 2019) and try to memorize which breed was uncomfortable during the extreme conditions (heat waves, long rainy season, parasitic attack or endemicity). Results were in accordance with those of Chagunda et al. (2006) and Gerloff (2002) who spotted the importance of record-keeping in dairy farming.

The farming community in the study area reported that vaccination of hemorrhagic septicemia, vaccination of foot and mouth disease and vaccination of black quarter was the frequent Field services to the livestock farmers. Results were somewhat in line with the claim of GOP (2016) which reported that during 2016-17 total of 2267017 animals against HS, 7223948 against FMD, 2183795 against BQ were vaccinated in Rahim Yar Khan District. These results were not in accordance with those of Annas et al. (2015) where they summarized that vaccination of animals against hemorrhagic septicemia was not fully implemented before the monsoon set and lots of animals suffer in this curse. Khan et al. (2016) discussed against the current results as they found FMD remains mostly uncontrolled in Pakistan, vaccination is not practiced, being practiced by a small portion of farmers. Mobile veterinary service is available only on a fixed schedule most importantly they don't have follow-up plans. Jena and Chander (2018) in their study question about the poor fallow up plans and frequent visits in the same village. Frequent visits allow farmers and veterinary officers to understand the situation of animals and treatment history. Khan et al (2013) made the same claim based on finding that restricted animal health services were the one the main reason for poor farm production. They further explored that public department hardly reaches to the one-third of the total population. Kwaghe et al. (2015) mentioned that poor practices of veterinary in developing countries setbacks in livestock production hence posing a significant threat to 
animal and human health, food quality, food safety, food security.

Education was statistically significant $(\mathrm{P}<0.05)$ and positively associated with vaccination, disease prevention, parasite control, separate cattle pen. Educated people likely to invest in exotic animals than indigenous which are more resistant. With the unit rise in educational level, there is a possibility of $10,70,30$ and $20 \%$ more adoption of vaccination, disease prevention, parasitic control and separate cattle pen respectively. Results were supported by a couple of studies like Rehaman et al. (2012), Saqib et al. (2016) and Ullah et al. (2018) in which they reported education was a determent factor of farmers' adoption in the field.

Conclusion: Disease Control is essential for profitable livestock farming. Livestock in Pakistan is exposed to numerous zoonotic and other infectious diseases which decrease farm production. From the result, it can be reported that farmers had poor knowledge about the different diseases and parasite attack. Some farmers were even unaware of the problem their animals were facing. The farming community itself was making a full effort to fight against the disease. They do what makes sense to them in a particular situation at the farm. Most of the strategies adopted by the farmers are preventive type. Education of the farmer was a key indicator that was statistically significant $(\mathrm{P}<0.05)$ and positively associated with vaccination of the animal (0.014), disease prevention measure (0.075), parasite control (0.036), separate cattle pen for the diseased animal (0.026). The public institutional role seems to be restricted to the vaccination. Furthermore, this vaccination service was very limited. The livestock sector has an open field and it can be improved with some serious effort of the public sector and adoption of better management practices by the farmers. Prevention, control, containment and eradication of scheduled animal diseases will take the herder into a comfortable zone.

\section{REFERENCES}

Abdullah, M. 2009. Milk Production Systems In Robinson P. H. and U. Krishnamoorthy (Eds.), Dairy Nutrition Pakistan. American Soybean Association-International Marketing, Pakistan. pp. 35-50.

Ahmad, Z., Z. Anwar, M. Adnan, N. Imtiaz, H.U. Rashid and F. Gohar. 2019. Collection and prevalence of ticks in cattles and buffaloes from free-range management systems of islamabad. JOBAZ. 80:1-12.

Annas, S., M. Zamri-Saad, F. Jesse and Z. Zunita. 2015. Comparative clinicopathological changes in buffalo and cattle following infection by pasteurella multocida B: 2 . Microb. Pathog. 88:94-102.

Ashfaq, M., A. Razzaq and G. Muhammad. 2015. Economic analysis of dairy animal diseases in Punjab: A case study of Faisalabad district. J Anim. Plant Sci.. 25:1482-1495.
Ashfaq, M., G. Muhammad and A.R. Shamsheer-ul-Haq. 2014. Effects of livestock diseases on dairy production and in-comes in district Faisalabad, Punjab, Pakistan. Pakistan Strategy Support Program-International Food Policy Research Institute Working Paper.

Ashraf, S., Z. Hassan and I. Ashraf. 2019. Dynamics of agricultural extension services in pakistan: A history of national performance. J Anim Plant Sci. 29:1707-1717.

Benkirane, A. and M. De Alwis. 2002. Haemorrhagic septicaemia, its significance, prevention and control in asia. Vet Med (Praha). 47:234-240.

Biegelmeyer, P., L. Nizoli, S. Da Silva, T. dos Santos, N. Dionello, C. Gulias-Gomes and F. Cardoso. 2015. Bovine genetic resistance effects on biological traits of rhipicephalus (boophilus) microplus. Vet. Parasitol. 208:231-237.

Chagunda, M.G.G., Msiska, A.C.M., Wollny, C.B.A., Tchale, H. and Banda, J.W., 2006. An analysis of smallholder farmers' willingness to adopt dairy performance recording in Malawi. Livest Res Rural Dev. 18:1-6.

Davidson, E.A., L.V. Verchot, J.H. Cattanio, I.L. Ackerman and J. Carvalho. 2000. Effects of soil water content on soil respiration in forests and cattle pastures of eastern Amazonia. Biogeochemistry. 48:53-69.

Deb, G.K., T.N. Nahar, P.G. Duran and G.A. Presicce. 2016. Safe and sustainable traditional production: The water buffalo in Asia. Front Environ Sci Eng. 4:1-7.

DeGaris, P.J. and I.J. Lean. 2008. Milk fever in dairy cows: A review of pathophysiology and control principles. Vet. J. 176:58-69.

Dejene, S.W., I.M. Heitkönig, H.H. Prins, F.A. Lemma, D.A. Mekonnen, Z.E. Alemu, T.Z. Kelkay and W.F. de Boer. 2016. Risk factors for bovine tuberculosis (btb) in cattle in Ethiopia. PLoS One. 11:e0159083.

Derner, J.D., L. Hunt, K. Euclides Filho, J. Ritten, J. Capper and G. Han. 2017. Livestock production systems. In Rangeland systems: Springer, Cham. 347-372.

Devendra, C. 2005. Small ruminants in asia; contribution to food security, poverty alleviation and opportunities for productivity enhancement. Paper read at Proceeding of international workshop on small ruminant production and development in South East Asia. MEKARN, Nong Lam, HCMC, Vietnam.

FAO 2020. Dairy market review. March 2020. http://www.fao.org/3/ca8341en/CA8341EN.pdf

FAO. 2014. Impact of mastitis in small scale dairy production systems. Animal Production and Health Working Paper. No. 13. Rome. http://www.fao.org/3/a-i3377e.pdf

FAO. 2019. Dairy Market Review, March, 2019. Rome. http://www.fao.org/3/ca3879en/ca3879en.pdf

FAO. 2021. World Cattle Inventory: Ranking Of 209 Countries (FAO). Beef Market Central. https://beef2live.com/story-world-cattle-inventoryranking-209-countries-fao-247-127843. 
Faraz A, A. Waheed , H. M. Ishaq, R. H. Mirza 2019. Rural Development by Livestock Extension Education in Southern Punjab. J Fisheries Livest Prod 7: 287. doi: 10.4172/2332-2608.1000287

Faraz, A. 2019. Sahiwal - a famous cattle breed of Pakistan. SCAP Publishers Faisalabad. 5: 1-9. https://www.researchgate.net/publication/338765362_S ahiwal_-_a_famous_cattle_breed_of_Pakistan

Faraz, S., 2018. Beef industry in Pakistan. SCAP Publishers Faisalabad. 3: 1-10.

Fareed, S.K., K.H. Memon, A.B. Kachiwal, S. Azhar, M.I. Brula, M. Ali and T.A. Khan. 2017. Prevalence and economic losses of reproductive disorders and mastitis in buffaloes at Karachi, Pakistan. Indian J. Anim. Res. 51:1130-1133.

Farooq, M.Z., B.N. Siddiqui, K. Masud, M.R.A. Khan, M. Ali, A. Rayit, S.A.A. Shah, K.M. Dawood and G. Naeem. 2020. Comparison between public and private extension services for sugarcane production in muzaffargarh district, punjab, pakistan. J. Agric. Ext. Rural Dev. 12:15.

Ferrari, G., L. Tasciotti, E. Khan and A. Kiani. 2014. Footand-mouth disease and its effect on milk yield: An economic analysis on livestock holders in Pakistan. Transbound Emerg Dis. 61:52-59.

Fikadu, W., D. Tegegne, N. Abdela and W.M. Ahmed. 2016. Milk fever and its economic consequences in dairy cows: A review. Glob. Vet. 16:441-452.

Gerloff, D.C. 2002. Establishing and using a farm financial record-keeping system: The University of Tennessee Agricultural Extension Service. https://trace.tennessee.edu/cgi/viewcontent.cgi?article $=1$ 000\&context=utk_agexfinman

Gharbi, M., L. Sassi, P. Dorchies and M.A. Darghouth. 2006. Infection of calves with theileria annulata in tunisia: Economic analysis and evaluation of the potential benefit of vaccination. Vet. Parasitol. 137:231-241.

GOP 2016. Enhancement of Livestock Production and Productivity through Strategic Deworming and Vaccination. Midterm report (Jul 2016 - June 2017). Livestock \& dairy development government of Punjab pp.19-20.

http://9211.com.pk/LiveStockAdmin/uploads/item_files /disease_controlled_compartments_sbxpx.pdf

GOP 2020. Pakistan Economic Survey. Economic Adviser's Wing, Finance Division Government of Pakistan, Islamabad Economic Adviser's Wing, Finance Division Government of Pakistan, Islamabad

Govt. of Punjab. 2016. Punjab portal all about Punjab at one place. https://punjab.gov.pk/about_punjab_culture

Govt. of Punjab. 2018. Livestock census Punjab 2018 first real time (door to door) livestock census big dataanalytics. Livestock \& dairy development department 2-Bank Road, Old P\&D Building, Punjab
Civil Secretariat, Lahore, Pakistan. Available at http://livestockPunjab.gov.pk/LiveStockAdmin/uploads/ editor_files/livestock_census_pu njab_2018_saygg.pdf

Gwakisa, P., K. Yoshihara, T.L. To, H. Gotoh, F. Amano and E. Momotani. 2001. Salivary gland extract of rhipicephalus appendiculatus ticks inhibits in vitro transcription and secretion of cytokines and production of nitric oxide by lps-stimulated ja-4 cells. Vet. Parasitol. 99:53-61.

Haleem, S., S. Niaz, N.A. Qureshi, R. Ullah, M.S. Alsaid, A.S. Alqahtani and A.A. Shahat. 2018. Incidence, risk factors, and epidemiology of cystic echinococcosis: A complex socioecological emerging infectious disease in Khyber Pakhtunkhwa, province of Pakistan. Biomed Res Int. 2018. Article ID 5042430.

Hasnain, H. and R. Usmani. 2006. Livestock of Pakistan. Livestock Foundation, Islamabad, Pakistan. 154.

Hegde, N.G. 2019. Buffalo husbandry for sustainable development of small farmers in India and other developing countries. AJRAVS. 3:1-20.

Idrees, M., Z. Mahmood, D. Hussain, M. Shafi and U. Sidique. 2007. General problems regarding extension services with livestock and dairy farmers of Peshawar district, Pakistan. Sarhad J. Agric. 23:527-531.

Ishaq, M., A. Hassan, A. Farooq and L. Xiangsen. 2016. Survey of livestock production and management in khyber Pakhtunkhwa province of Pakistan. Pak. J. Agric . Sci. 53: 473-481.

Jabbar, A., T. Abbas, H.A. Saddiqi, M.F. Qamar and R.B. Gasser. 2015. Tick-borne diseases of bovines in pakistan: Major scope for future research and improved control. Parasit Vectors. 8:283.

Jamal, S.M., S. Ahmed, M. Hussain and Q. Ali. 2010. Status of foot-and-mouth disease in Pakistan. Arch. Virol. 155:1487-1491.

Jena, A. and M. Chander. 2018. Improving livestock services delivery by mobile veterinary units in odisha. J. Ext. Educ. 29: 5857-5862.

Khan, A., M.H. Mushtaq, M. ud din Ahmad, Z. Fatima and A. Khan. 2016. Seasonal trends in seroprevalence of FMD in bovines under different environmental conditions in rural KPK, Pakistan. Pak. Vet. J. 37: 55-58.

Khan, K., G. Khan, M. Zahri and M. Altaf. 2015. Role of livestock in poverty reduction: A case study of district lasbela, Balochistan. Lasbela, UJ Sci. Techl.pp. 153-156.

Khan, M., A. Mahmood, M. Younus and F. Nazir. 2013. Prompt community based veterinary services delivery system and it's impact on disease burden and production in the dairy animals. Mortality. J Anim Plant Sci. 23:1012.

Klein, J., M. Hussain, M. Ahmad, M. Afzal and S. Alexandersen. 2008. Epidemiology of foot-and-mouth disease in landhi dairy colony, Pakistan, the world largest buffalo colony. Virol. J. 5:53. 
Kwaghe, A.V., C.T. Vakuru, M.D. Ndahi, J.G. Usman, A. Abubakar and V.N. Iwar. 2015. Veterinary services as a panacea for agricultural development and increase in Nigeria's gross domestic product (GDP): A review. Int. J. Life Sci. 4:134-146.

Lopes, L., R. Nicolino, R. Capanema, C. Oliveira, J. Haddad and C. Eckstein. 2015. Economic impacts of parasitic diseases in cattle. CAB Reviews. 10:1-10.

MacDonald, J., E. O'Donoghue and W. McBride. 2006. Changes in the size and location of us dairy farms. Profits, costs, and the changing structure of dairy farming.pp. 2-4.

Mangan, T. and U. Ruthbah. 2018. Preliminary report on the growers' and marketing channel surveys (chilli) in Sindh. Policy and Institutional Reforms to Improve Horticultural Markets in Pakistan: ACIAR Project.pp. 2014.43:

Martin, G., K. Barth, M. Benoit, C. Brock, M. Destruel, B. Dumont, M. Grillot, S. Hübner, M.-A. Magne and M. Moerman. 2020. Potential of multi-species livestock farming to improve the sustainability of livestock farms: A review. Agric. Syst. 181:102821.

Miller, B.A. and C.D. Lu. 2019. Current status of global dairy goat production: An overview. Asian-Australas J Anim Sci. 32:1219-1232.

Moustafa, A., S. Ali, M. Bennett, T. Hyndman, I. Robertson and J. Edwards. 2017. A case-control study of haemorrhagic septicaemia in buffaloes and cattle in Karachi, Pakistan, in 2012. Transbound Emerg Dis. 64:520-527.

Pakistan Economic Survey. 2018. Government of Pakistan Ministry of finance http://www.finance.gov.pk/survey/chapters_18/02Agriculture.pdf

Proudfoot, K.L., M. Jensen, D. Weary and M. Von Keyserlingk. 2014. Dairy cows seek isolation at calving and when ill. J. Dairy Sci. 97:2731-2739.

Provisional Census Results, 2017. Province Wise Provisional Results of Census - 2017. http://www.pbs.gov.pk/sites/default/files/PAKISTAN\% 20TEHSIL\%20WISE\%20FOR\%20WEB\%20CENSUS _2017.pdf

Randhawa, A., H. Magsi and A. Shah. 2018. Growth performance of meat production and export in Pakistan: An analysis. JAPS, J Anim Plant Sci. 28:883-888.

Rashid, M., H. Akbar, I. Rashid, K. Saeed, L. Ahmad, A.S. Ahmad, W. Shehzad, S. Islam and S. Farooqi. 2018. Economic significance of tropical theileriosis on a Holstein Friesian dairy farm in Pakistan. J. Parasitol. 104:310-312.

Rashid, M., M.I. Rashid, H. Akbar, L. Ahmad, M.A. Hassan, K. Ashraf, K. Saeed and M. Gharbi. 2019. A systematic review on modelling approaches for economic losses studies caused by parasites and their associated diseases in cattle. Parasitology. 146:129-141.

Raza, M.H., G.A. Khan, B. Shahbaz and M.F. Saleem. 2020. Effectiveness of information and communication technologies as information source among farmers in Pakistan. Pak. J. Agri. Sci. 57:281-288.

Rehaman, N.U., J. Khan and M. Tariq. 2012. The impact of education on agricultural production in Khyber Pakhtunkhwa province of Pakistan (1975-2008). Sarhad J. Agric. 28:345-352

Rehman, A., A.M. Nijhof, C. Sauter-Louis, B. Schauer, C. Staubach and F.J. Conraths. 2017. Distribution of ticks infesting ruminants and risk factors associated with high tick prevalence in livestock farms in the semi-arid and arid agro-ecological zones of Pakistan. Parasites Vectors. 10:190.

Saqib, S., M.M. Ahmad, S. Panezai and U. Ali. 2016. Factors influencing farmers' adoption of agricultural credit as a risk management strategy: The case of Pakistan. Int. J. Disaster Risk Reduct. 17:67-76.

Sarker, M.S.A., M.E. El Zowalaty, M. Shahid, M. Sarker, M.B. Rahman, J.D. Järhult and K. Nazir. 2020. Maximization of livestock anthrax vaccination coverage in Bangladesh: An alternative approach. Vaccines. 8:435.

Sarwar, M., M.A. Khan and Z. Iqbal. 2002. Status paper feed resources for livestock in Pakistan. Int. J. Agric. Biol. 4:186-192.

Shahbaz, B. and S. Ata. 2014. Enabling agricultural policies for benefiting smallholders in dairy, citrus and mango industries of Pakistan-project no. Adp/2010/091.

Shahid, H., O. Shafique and A. Shokat. 2012. Dairy industry of Pakistan. EJBMR 4:1-4.

Sidhu, R. and A. Bhullar. 2004. Changing structure of the farm economy in Punjab: Impact of livestock on income and employment. Indian J. Agric. Econ. 59: 578-587.

Singh, B., N.K. Dhand and J. Gill. 2015. Economic losses occurring due to brucellosis in Indian livestock populations. Prev. Vet. Med. 119:211-215.

Thilsing-Hansen, T., R.J. Jorgensen, J. Enemark, R. Zelvyte and A. Sederevicius. 2003. The effect of zeolite a supplementation in the dry period on blood mineral status around calving. Acta Vet. Scand. Suppl. 97:87-95.

Thornton, P.K. 2010. Livestock production: Recent trends, future prospects. Philosophical Transactions of the Royal Society B: Biol. Sci. 365:2853-2867.

Ullah, A., D. Khan, S. Zheng and U. Ali. 2018. Factors influencing the adoption of improved cultivars: A case of peach farmers in Pakistan. Cienc. Rural. 48:11.

Ullah, A., U.S. Khattak, S. Ayaz, M.S. Qureshi, I. Khan, I.U. Jan, I. Khattak, R. Taj, S. Nigar and N.U. Khan. 2019. Bovine tuberculosis (bTB): Prevalence and associated risk factors in large ruminants in the central zone of Khyber Pakhtunkhwa, Pakistan. Pak. J. Zool.51:127-133. 